\title{
Fulminant Type 1 Diabetes Mellitus Associated with Coxsackie Virus Type A2 Infection: A Case Report and Literature Review
}

\author{
Nobumasa Ohara ${ }^{1,2}$, Masanori Kaneko ${ }^{1,2}$, Takeaki Nishibori ${ }^{3}$, Kazuhiro Sato ${ }^{4}$, \\ Tatsuo Furukawa ${ }^{5}$, Tadashi Koike ${ }^{5}$, Hirohito Sone ${ }^{2}$, Kenzo Kaneko ${ }^{1}$ and Kyuzi Kamoi ${ }^{6}$
}

\begin{abstract}
A 65-year-old Japanese man presented to our hospital in June 2013 with a 6-day history of fever and fatigue, a 24-h history of thirst, and polyuria. His temperature was $37.8^{\circ} \mathrm{C}$ and he was alert. However, laboratory tests revealed severe hyperglycemia, undetectable C-peptide levels, and diabetic ketoacidosis. Serum antibody testing confirmed a Coxsackie virus A2 infection. A variety of viral infections are reported to be involved in the development of fulminant type 1 diabetes mellitus (FT1D). Our patient is the first reported case of FT1D associated with Coxsackie virus A2 infection and supports the etiological role of common viral infections in FT1D.
\end{abstract}

Key words: fulminant type 1 diabetes mellitus, Coxsackie virus A2, common cold, antiviral antibody, pancreatic enzyme, insulin therapy

(Intern Med 55: 643-646, 2016)

(DOI: 10.2169/internalmedicine.55.5292)

\section{Introduction}

Coxsackie viruses, single-stranded RNA viruses of the genus enterovirus, family picornavirus, are divided into two subgroups: A and B (1-3). At least 23 serotypes [serotypes 1 to 22 and 24] of group A and six serotypes [serotypes 1 to 6] of group B are recognized. The clinical manifestations of Coxsackie virus infections in humans are diverse, irrespective of subgroup or serotype and range from asymptomatic infections and common colds to fatal cases of flaccid paralysis or encephalitis.

Fulminant type 1 diabetes mellitus (FT1D) is a subtype of type 1 diabetes mellitus that is characterized by the abrupt onset of insulin-deficient severe hyperglycemia and diabetic ketoacidosis (DKA), which occurs within a few days (4). Most reported patients have been from East Asia, particularly Japan; cases from other regions or involving Cauca- sians are rare $(5,6)$. It has been hypothesized that a viral infection may play a role in the pathogenesis of FT1D through the rapid and almost complete destruction of pancreatic beta cells. Studies have reported a variety of viral infections, including Coxsackie virus B1, B3, B4, A4, A5, and A6, to be involved in the development of $\operatorname{FT1D}(7,8)$.

We herein report the case of a patient who developed FT1D accompanied by a Coxsackie virus A2 infection. In addition, all 22 previously reported cases in which a virus infection was considered to be involved in the development of FT1D are reviewed (7-21).

\section{Case Report}

A 65-year-old Japanese man who presented with acute thirst and polyuria in June 2013 was admitted to our hospital with a diagnosis of DKA. His medical history was unremarkable, with the exception of mild anemia and dyslipide-

\footnotetext{
${ }^{1}$ Department of Endocrinology and Metabolism, Nagaoka Red Cross Hospital, Japan, ${ }^{2}$ Department of Hematology, Endocrinology and Metabolism, Niigata University Faculty of Medicine, Japan, ${ }^{3}$ Department of Infectious Disease, Nagaoka Red Cross Hospital, Japan, ${ }^{4}$ Department of Respiratory Medicine, Nagaoka Red Cross Hospital, Japan, ${ }^{5}$ Department of Hematology, Nagaoka Red Cross Hospital, Japan and ${ }^{6}$ Center of Diabetes, Endocrinology and Metabolism, Joetsu General Hospital, Japan

Received for publication March 7, 2015; Accepted for publication June 11, 2015

Correspondence to Dr. Nobumasa Ohara, oharan@med.niigata-u.ac.jp
} 
Table 1. Laboratory Findings at the Time of Admission (June 2013).

\begin{tabular}{|c|c|c|}
\hline \multicolumn{3}{|l|}{ Hematology } \\
\hline Red blood cells & $402 \times 10^{4} / \mu \mathrm{L}$ & $(427-571)$ \\
\hline Hemoglobin & $11.9 \mathrm{~g} / \mathrm{dL}$ & $(12.4-17.2)$ \\
\hline Hematocrit & $35.5 \%$ & $(38.7-50.3)$ \\
\hline White blood cells & $11,190 / \mu \mathrm{L}$ & $(4,000-9,000)$ \\
\hline Neutrophils & $87.6 \%$ & $(36.0-71.0)$ \\
\hline Eosinophils & $0.0 \%$ & $(<11.0)$ \\
\hline Basophils & $0.3 \%$ & $(<1.5)$ \\
\hline Monocytes & $4.0 \%$ & $(<10.0)$ \\
\hline Lymphocytes & $8.1 \%$ & $(20.0-50.0)$ \\
\hline Platelets & $28.4 \times 10^{4} / \mu \mathrm{L}$ & $(12.0-30.0)$ \\
\hline \multicolumn{3}{|l|}{ Chemistry } \\
\hline Casual plasma glucose & $48.3 \mathrm{mmol} / \mathrm{L}$ & $(3.9-7.8)$ \\
\hline Serum C-peptide & $<0.2 \mathrm{ng} / \mathrm{mL}$ & \\
\hline Serum immunoreactive insulin & $<0.5 \mu \mathrm{U} / \mathrm{mL}$ & \\
\hline HbAlc (NGSP) & $6.2 \%$ & $(4.6-6.2)$ \\
\hline Glycoalbumin & $20.9 \%$ & $(11.6-16.4)$ \\
\hline Acetoacetate & $1,275 \mu \mathrm{mol} / \mathrm{L}$ & $(<55)$ \\
\hline 3-Hydroxybutyrate & $6,225 \mu \mathrm{mol} / \mathrm{L}$ & $(<85)$ \\
\hline Total protein & $6.7 \mathrm{~g} / \mathrm{dL}$ & $(6.7-8.3)$ \\
\hline Albumin & $3.7 \mathrm{~g} / \mathrm{dL}$ & $(3.8-5.3)$ \\
\hline Total cholesterol & $206 \mathrm{mg} / \mathrm{dL}$ & $(130-220)$ \\
\hline Triglycerides & $94 \mathrm{mg} / \mathrm{dL}$ & $(50-130)$ \\
\hline Aspartate aminotransferase & $19 \mathrm{IU} / \mathrm{L}$ & $(13-33)$ \\
\hline Alanine aminotransferase & $19 \mathrm{IU} / \mathrm{L}$ & $(8-42)$ \\
\hline Amylase & $276 \mathrm{IU} / \mathrm{L}$ & $(41-112)$ \\
\hline Lipase & $80 \mathrm{U} / \mathrm{L}$ & $(5-35)$ \\
\hline Elastase-1 & $3,406 \mathrm{ng} / \mathrm{mL}$ & $(<300)$ \\
\hline Phospholipase A2 & $890 \mathrm{ng} / \mathrm{dL}$ & $(130-400)$ \\
\hline Urea nitrogen & $30.5 \mathrm{mg} / \mathrm{dL}$ & $(8.0-22.0)$ \\
\hline Creatinine & $1.12 \mathrm{mg} / \mathrm{dL}$ & $(0.60-1.10)$ \\
\hline Sodium & $130 \mathrm{mmol} / \mathrm{L}$ & $(137-147)$ \\
\hline Potassium & $5.8 \mathrm{mmol} / \mathrm{L}$ & $(3.5-4.7)$ \\
\hline Chloride & $94 \mathrm{mmol} / \mathrm{L}$ & $(98-108)$ \\
\hline C-reactive protein & $5.81 \mathrm{mg} / \mathrm{dL}$ & $(<0.30)$ \\
\hline \multicolumn{3}{|c|}{ Arterial blood gas analysis under room air } \\
\hline $\mathrm{pH}$ & 7.291 & $(7.35-7.45)$ \\
\hline Partial carbon dioxide pressure & $25.2 \mathrm{mmHg}$ & $(32-48)$ \\
\hline Partial oxygen pressure & $99.6 \mathrm{mmHg}$ & $(83-108)$ \\
\hline Bicarbonate & $11.8 \mathrm{mmol} / \mathrm{L}$ & $(21-28)$ \\
\hline \multicolumn{3}{|l|}{ Urinalysis } \\
\hline Specific gravity & 1.033 & $(1.006-1.030)$ \\
\hline Glucose & $4+$ & $(-)$ \\
\hline Protein & - & $(-)$ \\
\hline Ketone bodies & $3+$ & $(-)$ \\
\hline Occult blood & \pm & $(-)$ \\
\hline White blood cells & - & $(-)$ \\
\hline
\end{tabular}

mia, which had been treated with fluvastatin $(20 \mathrm{mg} /$ day $)$ since he was 50 years of age. One of his brothers had rheumatoid arthritis. The patient developed a fever and fatigue 6 days before admission. Five days later, he developed thirst and polyuria and was treated with a general cold drug at a local hospital. However, his symptoms worsened, and he visited our hospital the next day.

On admission, the patient was alert, and his body temperature was $37.8^{\circ} \mathrm{C}$. He had fatigue, thirst, and polyuria, but did not complain of headache, sore throat, myalgia, or respiratory or abdominal symptoms. He was $170 \mathrm{~cm}$ tall and weighed $61 \mathrm{~kg}$. His blood pressure was $100 / 38 \mathrm{mmHg}$ and his pulse rate was 94 beats per minute. His oral cavity was dry, but no redness or white patches were observed on the pharynx and no vesicular rash or ulcers were observed on the oral mucous membrane. No chest rales or heart murmurs were detected. His abdomen was soft, flat, and non-tender, and his bowel sounds were normal. There was no exanthema on the skin, swelling of the superficial lymph nodes, muscle weakness, or peripheral edema. An arterial blood gas analysis revealed metabolic acidosis (Table 1). The laboratory findings showed a high white blood cell count, mild anemia, ketonemia, and severe hyperglycemia with normal HbA1c (NGSP) and a high serum glycoalbumin level. In addition, the patient's serum levels of creatinine, urea nitrogen, C-reactive protein, and exocrine pancreatic enzymes, including amylase, lipase, elastase-1, and phospholipase A2, were high. Chest and abdominal computed tomography detected fatty deposition in the liver, but no abnormalities were found in the lungs, pancreas, spleen, or kidneys. Blood and urine cultures were negative. He was diagnosed with DKA and acute renal failure and was treated with intravenous saline and regular insulin.

By the next morning, the patient's thirst and polyuria had resolved, and his temperature $\left(36.7^{\circ} \mathrm{C}\right)$, blood pressure $(105 /$ $51 \mathrm{mmHg}$ ), and pulse rate (59 beats per minute) had normalized. His plasma glucose had fallen to $9.2 \mathrm{mmol} / \mathrm{L}$, and his electrolytes were normal. Subcutaneous insulin injection therapy with insulin aspart and insulin glargine was initiated that morning.

On day 7 of admission, the patient's blood chemistry showed improvements in inflammation (white blood cells, 3,970/ $\mu \mathrm{L}$; serum C-reactive protein, $0.29 \mathrm{mg} / \mathrm{dL}$ ) and renal function (serum creatinine, $0.72 \mathrm{mg} / \mathrm{dL}$; urea nitrogen, 11.1 $\mathrm{mg} / \mathrm{dL})$. His fasting serum C-peptide was undetectable $(<0.2$ $\mathrm{ng} / \mathrm{mL}$ ) before and 5 minutes after intravenous glucagon loading, indicating FT1D. He tested negative for islet-related autoantibodies, such as glutamic acid decarboxylase antibody $(<1.3 \mathrm{U} / \mathrm{mL})$, insulinoma-associated antigen-2 antibody $(<0.4 \mathrm{U} / \mathrm{mL})$, islet cell antibody $(<1.25 \mathrm{JDF}$ units $)$, insulin antibody $(<125.0 \mathrm{nU} / \mathrm{mL})$, and zinc transporter- 8 antibody $(<10.0 \mathrm{U} / \mathrm{mL})$. He was also negative for other organ-specific autoantibodies, such as pituitary cell antibody, thyroid peroxidase antibody, thyroglobulin antibody, thyroid-stimulating hormone receptor antibody, gastric parietal cell antibody, intrinsic factor antibody, and the adrenal cortex antibody. $\mathrm{Hu}-$ man leukocyte antigen (HLA) typing showed A*11/24, B* 51/67, and $C^{*} 07: 02 / 14: 02$ class I genes and DRB1*12:01/ 16:02, DQB $1 * 03: 03 / 05: 02, \mathrm{DQA} 1 * 01: 02 / 03: 02$, and DPB $1 *$ 02:02/05:01 class II genes.

The patient was discharged in July 2013 after completing a diabetes mellitus self-management education program. His serum levels of amylase, lipase, elastase-1, and phospholipase A2 remained high in August 2013 and then normalized in September of the same year.

The patient continued to undergo treatment with multiple daily insulin injection therapy with insulin aspart and insulin glargine (a total of $30 \mathrm{U} /$ day) as an outpatient. In January 2015, he weighed $56 \mathrm{~kg}$, and laboratory examinations showed the following results: HbA1c (NGSP) 9.3\%, casual plasma glucose $7.7 \mathrm{mmol} / \mathrm{L}$, and undetectable serum C- 
Table 2. Summary of Reported Patients with a Virus Infection Involved in the Development of Fulminant Type 1 Diabetes Mellitus.

\begin{tabular}{|c|c|c|c|c|c|c|c|c|c|c|}
\hline \multirow[b]{2}{*}{ Case } & \multirow[b]{2}{*}{ Sex } & \multirow[b]{2}{*}{$\begin{array}{l}\text { Age } \\
\text { (years) }\end{array}$} & \multirow[b]{2}{*}{$\begin{array}{l}\text { HLA- } \\
\text { DRB1 }\end{array}$} & \multirow[b]{2}{*}{$\begin{array}{l}\text { HLA- } \\
\text { DQB1 }\end{array}$} & \multicolumn{3}{|c|}{ Viral infection } & \multirow[b]{2}{*}{$\begin{array}{c}\text { Impaired } \\
\text { consciousness at } \\
\text { the onset of DKA }\end{array}$} & \multirow[b]{2}{*}{ Complicating disorders } & \multirow[b]{2}{*}{ Ref. } \\
\hline & & & & & Causal virus & Symptoms & $\begin{array}{c}\text { Appearance of } \\
\text { symptoms before } \\
\text { the onset of DKA }\end{array}$ & & & \\
\hline 1 & Female & 60 & [DR 4,12] & NA & Coxsackie B3 & None & - & $(+)$ & $\begin{array}{l}\text { DIHS (diaminodiphenyl } \\
\text { sulfone) on steroid therapy }\end{array}$ & 9 \\
\hline 2 & Female & 77 & 08:03/15:01 & 06:01/06:02 & HHV-6 and cytomegalovirus & None & - & $(+)$ & $\begin{array}{l}\text { DIHS (carbamazepine) on } \\
\text { steroid therapy }\end{array}$ & 7,10 \\
\hline 3 & Female & 26 & [DR 4,9] & [DQ 3,4] & Herpes simplex virus & $\begin{array}{l}\text { Fatigue, headache, } \\
\text { upper abdominal pain }\end{array}$ & 1 month & $(-)$ & Acute pancreatitis & 11 \\
\hline 4 & Female & 61 & [DR 2,4] & NA & HHV-6 & None & - & $(+)$ & $\begin{array}{l}\text { DIHS (mexiletine) on steroid } \\
\text { therapy }\end{array}$ & 12 \\
\hline 5 & Female & 35 & 04:05/15:02 & 04:01/06:01 & Coxsackie B3 & Fever, fatigue & 4 days & $(-)$ & None & 13 \\
\hline 6 & Male & 64 & $04: 05 /(-)$ & 04:01/(-) & Influenza virus B & High-grade fever & 8 days & $(+)$ & None & 14 \\
\hline 7 & Male & 23 & $04: 05 /(-)$ & NA & Rotavirus & $\begin{array}{l}\text { Drowsiness, nausea, } \\
\text { upper abdominal pain }\end{array}$ & NA & $(+)$ & NA & 7 \\
\hline 8 & Female & 45 & NA & NA & HHV-7 & $\begin{array}{l}\text { Fever, nausea, upper } \\
\text { abdominal pain }\end{array}$ & NA & NA & NA & 7 \\
\hline 9 & Male & 57 & $04: 05 /(-)$ & NA & Rotavirus, HHV-6, and EBV & $\begin{array}{l}\text { Fever, nausea, upper } \\
\text { abdominal pain }\end{array}$ & NA & NA & NA & 7 \\
\hline 10 & Male & 38 & NA & NA & Coxsackie B1 and A4 & Headache, nausea & NA & NA & NA & 7 \\
\hline 11 & Male & 34 & NA & NA & Coxsackie A6 & NA & NA & NA & NA & 7 \\
\hline 12 & Male & 39 & NA & NA & Coxsackie A5 & $\begin{array}{l}\text { Fever, headache, upper } \\
\text { abdominal pain }\end{array}$ & NA & NA & NA & 7 \\
\hline 13 & Male & 61 & NA & NA & Cytomegalovirus & $\begin{array}{c}\text { Fever, nausea, upper } \\
\text { abdominal pain, diarrhea }\end{array}$ & NA & NA & NA & 7 \\
\hline 14 & Female & 25 & NA & NA & Cytomegalovirus & $\begin{array}{l}\text { Fever, nausea, lower } \\
\text { abdominal pain }\end{array}$ & NA & NA & NA & 7 \\
\hline 15 & Male & 56 & 09:01/13:02 & 03:03/06:04 & Mumps virus & None & - & $(+)$ & None & 15 \\
\hline 16 & Female & 39 & $12: 01 /(-)$ & 03:03/04:02 & Coxsackie B4 & Nausea, fatigue & 4 days & $(-)$ & None & 8 \\
\hline 17 & Female & 49 & 04:05/15:02 & 04:01/05:02 & Cytomegalovirus & Flu-like symptoms & 2 months & $(-)$ & $\begin{array}{l}\text { Post kidney transplantation on } \\
\text { immunosuppression therapy }\end{array}$ & 16 \\
\hline 18 & Male & 38 & 04:03/13:02 & 03:02/06:04 & Hepatitis virus type A & $\begin{array}{l}\text { Fever, myalgia, } \\
\text { gastrointestinal symptoms }\end{array}$ & 1 month & $(-)$ & None & 17 \\
\hline 19 & Female & 70 & $15: 01 / 16: 02$ & 05:02/06:02 & EBV & Fever & 18 days & $(-)$ & $\begin{array}{l}\text { Multiple myeloma treated with } \\
\text { anti-cancer drugs and steroids }\end{array}$ & 18 \\
\hline 20 & Male & 60 & 04:05/09:01 & 03:03/04:01 & Parvovirus B19 & Erythema & 7 days & $(+)$ & None & 19 \\
\hline 21 & Male & 65 & 01:01/15:01 & 03:01/05:01 & Cytomegalovirus & Nausea, diarrhea & 4 days & $(+)$ & Pre-existing treated diabetes & 20 \\
\hline 22 & Female & 35 & $04: 05 /(-)$ & $04: 01 /(-)$ & Parainfluenza-3 & Fever, cough & 5 days & $(+)$ & Myocarditis & 21 \\
\hline$\circ$ & Male & 65 & $12: 01 / 16: 02$ & 03:03/05:02 & Coxsackie A2 & Fever, fatigue & 6 days & $(-)$ & None & $\begin{array}{c}\text { Presen } \\
\text { t case }\end{array}$ \\
\hline
\end{tabular}

All patients had diabetic ketoacidosis (DKA) or ketosis at the onset of fulminant type 1 diabetes mellitus.

All cases were Japanese, except for case 18, who was Korean.

The human leukocyte antigen (HLA)-DR and HLA-RQ serotypes are shown in square brackets.

EBV: Epstein-Barr virus, DIHS: drug-induced hypersensitivity syndrome, HHV: human herpesvirus, NA: not available

peptide. His subsequent clinical course has been uneventful.

\section{Paired serum antiviral antibody test}

Antibodies titers were measured in serum samples that were taken at the time of admission (June 2013) and 4 weeks after admission to test for rotavirus, adenovirus, echovirus 6 and 9, Coxsackie virus type A2-A7, A9, A10, A16 and B1-B6, parainfluenza virus 1-3, influenza virus A and B, Epstein-Barr virus, human herpes virus 6 and 7, cytomegalovirus, simple herpes virus, hepatitis $\mathrm{A}, \mathrm{B}$, and $\mathrm{C}$ viruses, mumps, and parvovirus B19. Of these, a significantly elevated antibody titer was only detected against Coxsackie virus type A2 (more than three steps: from a titer $<1: 4$ to a titer 1:32) by a neutralization test (Nissui Pharmaceutical, Tokyo, Japan). The titer remained high 3 months (1:32), 6 months (1:32), and 1 year (1:32) after admission.

\section{Discussion}

The patient developed severe hyperglycemia and DKA with normal HbA1c (NGSP) and undetectable C-peptide levels after 1 day of hyperglycemic symptoms. These findings are consistent with a diagnosis of FT1D (23). The presence of elevated serum pancreatic enzymes, negativity for verifiable islet-related autoantibodies, and pre-existing flulike symptoms support this diagnosis.

Coxsackie A2 virus infection, although asymptomatic in many cases, produces common colds, gastroenteritis, respiratory illness, and exanthema (1-3). It can also cause herpangina; less frequent manifestations include aseptic meningitis, paralysis, myocarditis, or hemolytic uremic syndrome. Our patient presented with fever and fatigue without any other symptoms before developing FT1D, and the Coxsackie A2 virus infection was confirmed serologically.

Table 2 summarizes the reported cases in which virus infection was proven to be involved in the development of FT 1D (7-21). These cases include adults of both sexes. All of the patients were Japanese, except for case 18, who was Korean (17). Some of the patients had the class II HLA DRB1*04:05-DQB $1 * 04: 01$ or $\mathrm{DRB} 1 * 09: 01-\mathrm{DQB} 1 * 03: 03$ 
haplotype, which increase the susceptibility of Japanese individuals to FT1D (24). Many of the patients presented with flu-like or gastrointestinal symptoms, regardless of the causative virus and quickly developed FT1D with or without diabetic coma. Our patient is the first reported case of FT1D to be associated with Coxsackie virus A2 infection. This case supports the etiological role of common viral infections in the development of FT1D.

In conclusion, our patient developed a Coxsackie virus A2 infection that manifested as fever and fatigue and which was involved in the development of FT1D. This case highlights the need to assess individuals with both common colds and acute hyperglycemic symptoms for the presence of DKA, even if they are alert when presenting to the hospital.

The authors state that they have no Conflict of Interest (COI).

\section{Acknowledgement}

We thank the clinical laboratory technicians of Nagaoka Red Cross Hospital for their helpful technical support.

\section{References}

1. Torres A, Garib J, Recurt ML. Coxsackie virus: a review. Bol Asoc Med P R 76: 49-51, 1984.

2. Hyypiä T, Stanway G. Biology of coxsackie A viruses. Adv Virus Res 42: 343-373, 1993.

3. Kaji M. Coxsackie virus. Nihon Rinsho (Japanese Journal of Clinical Medicine) 68 Suppl 6: 418-421, 2010 (in Japanese).

4. Imagawa A, Hanafusa T, Miyagawa J, Matsuzawa Y. A novel subtype of type 1 diabetes mellitus characterized by a rapid onset and an absence of diabetes-related antibodies. Osaka IDDM Study Group. N Engl J Med 342: 301-317, 2000.

5. Imagawa A, Hanafusa T. Fulminant type 1 diabetes mellitus. Endocr J 53: 577-584, 2006.

6. Moreau C, Drui D, Arnault-Ouary G, Charbonnel B, Chaillous L, Cariou B. Fulminant type 1 diabetes in Caucasians: a report of three cases. Diabetes Metab 34: 529-532, 2008.

7. The committee of Japan Diabetes Society on the research of fulminant type 1 diabetes mellitus. Report of Japan Diabetes Society's Committee on research on fulminant type 1 diabetes mellitus: analysis of antiviral antibodies at disease onset. Tonyobyo ( $\mathrm{J}$ Japan Diab Soc) 51: 531-536, 2008 (in Japanese, Abstract in English).

8. Akatsuka H, Yano Y, Gabazza EC, et al. A case of fulminant type 1 diabetes with coxsackie B4 virus infection diagnosed by elevated serum levels of neutralizing antibody. Diabetes Res Clin Pract 84: e50-e52, 2009.

9. Hashimoto N, Makino H, Kanatsuka A, et al. A case of insulindependent diabetes mellitus with coxsackie B3 virus following diaminodiphenyl sulphone (DDS) syndrome. Tonyobyo (J Japan Diab Soc) 30: 761-765, 1987 (in Japanese, Abstract in English).

10. Sekine N, Motokura T, Oki T, et al. Rapid loss of insulin secretion in a patient with fulminant type 1 diabetes mellitus and car- bamazepine hypersensitivity syndrome. JAMA 285: 1153-1154, 2001.

11. Nagaoka T, Terada M, Miyakoshi H. Insulin-dependent diabetes mellitus following acute pancreatitis caused by herpes simplex virus; a case report. Tonyobyo (J Japan Diab Soc) 44: 335-340, 2001 (in Japanese, Abstract in English).

12. Ohta $K$, Takamoto $T$, Izumi $H$, Yoshida $T$, Ishihara $Y$, Hirata Yukio. A case of fulminant type 1 diabetes mellitus during steroid therapy for hypersensitivity syndrome. Tonyobyo (J Japan Diab Soc) 44: 907-912, 2001 (in Japanese, Abstract in English).

13. Nishida W, Hasebe S, Kawamura R, et al. A case of fulminant type 1 diabetes associated with high titer of coxsackie B3 virus neutralizing antibodiy. Tonyobyo (J Japan Diab Soc) 48 (Suppl 1): A23-A27, 2005 (in Japanese).

14. Sano H, Terasaki J, Tsutsumi C, Imagawa A, Hanafusa T. A case of fulminant type 1 diabetes mellitus after influenza B infection. Diabetes Res Clin Pract 79: e8-e9, 2008.

15. Goto A, Takahashi Y, Kishimoto M, et al. A case of fulminant type 1 diabetes associated with significant elevation of mumps titers. Endocr J 55: 561-564, 2008.

16. Ohta M, Miura J, Ohsato A, et al. A case of fulminant type 1 diabetes mellitus undergoing immunosuppression therapy after kidney transplantation with cytomegalovirus antigenemia elevation. Tonyobyo (J Japan Diab Soc) 52: 919-925, 2009 (in Japanese, Abstract in English).

17. Hwang YC, Jeong IK, Chon S, et al. Fulminant Type 1 diabetes mellitus associated with acute hepatitis A. Diabet Med 27: 366367, 2010.

18. Fujiya A, Ochiai H, Mizukoshi $T$, et al. Fulminant type 1 diabetes mellitus associated with a reactivation of Epstein-Barr virus that developed in the course of chemotherapy of multiple myeloma. J Diabetes Investig 1: 286-289, 2010.

19. Nishiumi $T$, Okamoto $K$, Inamoto $S$, et al. Case of fulminant type 1 diabetes mellitus associated with parvovirus B19 infection. J Diabetes Investig 5: 472-473, 2014.

20. Okubo Y, Inaishi J, Kaneko S, Itoh A, Kondo K, Takei I. A case of slowly progressive insulin-dependent diabetes mellitus in which the patient developed diabetic ketoacidosis resembling the onset of fulminant type 1 diabetes mellitus. Tonyobyo (J Japan Diab Soc) 57: 791-796, 2014 (in Japanese, Abstract in English).

21. Ohara N, Kaneko M, Kuwano H, et al. Fulminant type 1 diabetes mellitus and fulminant viral myocarditis. Int Heart J 56: 239-244, 2015.

22. Committee on the Standardization of Diabetes Mellitus-Related Laboratory Testing of Japan Diabetes Society. International clinical harmonization of glycated hemoglobin in Japan: From Japan Diabetes Society to National Glycohemoglobin Standardization Program values. J Diabetes Invest 3: 39-40, 2012.

23. Imagawa A, Hanafusa $T$, Awata $T$, et al. Report of the Committee of the Japan Diabetes Society on the Research of Fulminant and Acute-onset Type 1 Diabetes Mellitus: new diagnostic criteria for fulminant type 1 diabetes mellitus (2012). J Diabetes Investig 3: 536-539, 2012.

24. Committee on Type 1 Diabetes, Japan Diabetes Society. Differential association of HLA with three subtypes of type 1 diabetes: fulminant, slowly progressive and acute-onset. Diabetologia 52: 2513-2521, 2009.

(C) 2016 The Japanese Society of Internal Medicine http://www.naika.or.jp/imonline/index.html 